\title{
Comparison of characteristics of Asian and non-Asian tourists visiting eco-lodges in Sri Lanka
}

\author{
H. D. P. Sumanapala ${ }^{1 \star}$, S. W. Kotagama ${ }^{1}$, P. K. P. Perera ${ }^{2}$, N. W. K. Galahitiyawe ${ }^{3}$ and D. A. C. S. Suranga ${ }^{4}$ \\ ${ }^{I}$ Department of Zoology, Faculty of Science, University of Colombo, Colombo, Sri Lanka. \\ ${ }^{2}$ Department of Forestry and Environmental Science, Faculty of Applied Sciences, University of Sri Jayewardenepura, Nugegoda, Sri Lanka. \\ ${ }^{3}$ Department of Decision Sciences, Faculty of Management Studies and Commerce, University of Sri Jayewardenepura, Nugegoda, Sri Lanka. \\ ${ }^{4}$ Department of Economics, Faculty of Arts, University of Colombo, Colombo, Sri Lanka.
}

\begin{abstract}
As the demand for ecotourism and nature-based tourism increases, eco-lodges are becoming a popular alternative accommodation choice. Consequently, the development of an ecolodge industry has wider implications for countries such as Sri Lanka, especially when considering the country's high potential for ecotourism and the need to provide alternative forms of accommodation for increasing tourist arrivals. In the Sri Lankan context, the eco-lodge industry still remains relatively undeveloped and the understanding of characteristics of visitors who seek accommodation in ecolodges is limited. In this study, the author distinguished Asian and non-Asian ecotourist market segments visiting ecolodges in Sri Lanka, to enable ecotourism operators and policy makers to better tailor their products to target groups. A survey of 362 ecolodge occupants in 16 selected ecolodges found that the Asian and non-Asian visitor segments differ in terms of travel motivations, their perceptions on various ecolodge attributes, trip characteristics and demographics. However, both age and level of education were found to be strongly related in other studies. The study found that non-Asian ecotourists stay for longer periods by comparison with Asian ecotourists. Seeking novel experiences appeared to be the main motivation of Asian ecolodge occupants, and they typically demanded physically challenging activities. Non-Asians' motivation was friendliness of the people of the host country, followed by visiting nature and learning local customs. The management implications of distinguishing the Asian and non-Asian market segments are discussed.
\end{abstract}

Keywords: Ecotourism, ecolodge patrons, visitor profiles, travel characteristics, Sri Lanka.

\section{INTRODUCTION}

The ecolodge industry has its roots in the late 1980s when negative environmental and social impacts of mass tourism activities became apparent, causing consumers around the world to demand so-called "green" tourism offerings (Sanders and Halpenny, 2001). Ecolodges are intended to be accommodation facilities that support environmental conservation, while providing economic benefits to host communities. Russell et al. (1995) defined ecolodge as a "nature-dependent tourist lodge that meets the philosophy and principles of ecotourism". It further offers natural resource-oriented activities and opportunities for learning about the environment (Lai and Shafer, 2005). Although there is no universally accepted definition for ecolodges, many contemporary tourism scholars (Weaver, 2001; Fennell, 2001; Mehta et al., 2002; Kawan et al., 2008; Raju, 2009; Erdem, 2013) have endorsed the core values and concepts described by Russell et al. (1995) in their definition of ecolodge, while promoting "ecolodge" as an industry label. Despite the heterogeneity in definitions, the demand for alternative accommodation options such as ecolodges is on the rise and ecolodges have evolved into one of the fast-growing sectors in the world's tourism accommodation business (Sumanapala et al., 2015).

Concurrent with the ecolodge industry, the literature on ecolodges is also growing. Several studies have profiled the characteristics of ecolodge patrons. Based on a visitor survey at two ecolodges in Lamington National Park, Queensland, Australia, Weaver and Lawton (2002) described three distinct ecotourist segments on the hardsoft spectrum. The hard-core ecotourists were found to be comparatively young, highly educated and not belonging to high-income brackets compared to other ecotourists. Soft-ecotourists on the other hand, demanded more 
comfort and facilities, guided tours and exhibited less commitment to environmental conservation. These were typically highly educated and high-income groups. Weaver and Lawton (2002) further described a visitor segment termed 'Structured' ecotourists, resembling characteristics of both hard and soft ecotourists, with high levels of commitment to the environment, yet expecting high levels of services and facilities. Kwan et al. (2008; 2010) investigated demographic characteristics, trip characteristics and travel motivations of ecolodge patrons in the Cayo District of Belize, and found that ecolodge patrons had some demographic characteristics similar to those of ecotourists described elsewhere (Chan and Baum, 2007; Sumanapala et al., 2015): middle-aged, highly educated and employed with high levels of income. Experiencing tropical forests and wilderness or undisturbed nature was the primary travel attraction motive of their visitation, while learning and exploring nature were top-ranked social motives. In the framework of push and pull motives, Chan and Baum (2007) explained that ecotourists are attracted by destination attributes such as natural attractions, wildlife, local lifestyle and where ecolodges are located ("pull" factors), and "pushed" by a social-psychological desire to escape from their routine of normal life by visiting ecolodges. Accordingly, ecotourists' motivational factors can be explained by employing "seeking" and "escaping" as motivational dimensions of leisure behaviour (Chan and Baum, 2007). Most published studies on ecolodge occupants have been conducted in North and Central America and Australia. Such studies in Asian regions are scarce in literature. In the Sri Lankan context, Sumanapala et al. (2015) surveyed 220 ecolodge occupants in 12 selected ecolodges and found that the majority of respondents were between the ages of 26 and 55 years, highly educated and having moderate to high incomes. In terms of trip characteristics, the majority of the respondents stayed in ecolodges for 1-3 days, and travelled with spouse or family. Natural and cultural features were among the main "pull" motives for selecting the destination. Internet, travel guide books and word-of-mouth were the major sources of information in selecting accommodation.

With rising demand, the ecotourism market is becoming more heterogeneous and previous studies on ecotourists have described different segments of ecotourists based on their demographic, behavioural and motivational characteristics (Kerstetter et al., 2004; Perera et al., 2012). As such, ecotourism operators, including the ecolodge business, are facing the task of meeting diverse expectations of ecotourism products. Given the diversity of ecotourists and those who seek accommodation in ecolodges, there is a strong need to further distinguish market segments in order to better understand different types of ecolodge occupants. This study attempted to further describe ecolodge patrons in Sri Lanka's ecolodges and differentiate market segments based on geographical origin.

\section{METHODOLOGY}

\section{Sampling frame}

The sample frame for this study included tourists who stayed at least one night at sixteen selected ecolodges in Dambulla, Kandy, Rathnapura and Hambantotha areas in Sri Lanka. The ecolodges were selected based on the subjective criteria of (i) the business is advertising itself as an ecolodge, (ii) the ecolodge management's endeavour to work with local community (iii) appear to cause minimal disturbance to surrounding natural environment (or making attempts to enhance natural resources), and (iv) offer interpretive guidance to visitors to educate them about surrounding natural and cultural environment (Sumanapala et al., 2015). However, the selected ecolodges showed heterogeneity in terms of lodging style, dining, amenities, nature-related activities, and quality of the interpretive guidance provided.

\section{Research tool}

A structured three-page questionnaire was the primary research tool used in this study. The first section contained questions on travel motivation and consisted of 14 motivational items that urged visitors to experience the stay at an ecolodge in Sri Lanka. These items were selected based on previous literature (Eagles and Cascagnette, 1995; Wight, 1996). The second section contained 25 ecolodge attributes and the respondents were asked to rank their satisfaction with each attribute. The ecolodge attributes used in the questionnaire were adopted from past studies (Atkinson, 1988; Callan and Kyndt, 2001; Callan and Bowman, 2000; Chu and Choi, 2000; LeBlanc and Nguyen, 1996; Oppermann and Chon, 1997; Wilensky and Buttle, 1988; Eagles, 1992; Hawkins et al., 1995; Mehta et al., 2002; WTO, 2002; Kozak, 2001; Akama and Kieti, 2003; Nepal, 2007) and modified to fit the Sri Lankan context. Each attribute was ranked on a 7-point Likert scale. Last section consisted of questions on travel characteristics and demographics.

During the period January 2014 to January 2015, the questionnaire was self-administered at sixteen selected ecolodges. Following the procedures used in Kawan et al. $(2008 ; 2010)$, the front-desk staff of the ecolodges 
were briefed by the researcher in advance about the study requirements and visitors were provided with the questionnaire during the check-in. Visitors were further informed that participation in the survey was voluntary. Occupants of each registered room at the ecolodge received a questionnaire. When there were two or more guests in one room or cabin, only one questionnaire was given. The guests sharing the same unit, decided who should respond to the questionnaire. On completion of the questionnaire, the respondents were asked to put the completed questionnaire in a drop box at the front desk during check out, or return it to the front desk. Those who declined to participate in the survey were treated as non-respondents. Statistical Package for Social Sciences (SPSS 20.0) was used for data analysis.

\section{Limitation of the study}

This study focuses on only sixteen ecolodges. Therefore, the sample size is relatively small. On the other hand, selection of attributes for each of the categories is based on actual knowledge and past research. There may be other attributes that are important to patrons in ecolodges. This study is a first attempt to explore this industry but its findings are likely to be useful for ecolodge managers and policy makers.

\section{RESULTS}

A total of 450 questionnaires were distributed among the sixteen ecolodges. At the end of the data collection period, a total of 362 were completed. After eliminating invalid questionnaires, this accounted for an adjusted response rate of $69.0 \%$.

\section{Demographic Characteristics}

Age group

Both groups showed similar age groups during the ecolodge occupancy (Table 1). More than $60 \%$ of respondents were of the age group 26-55 and from Asian regions; $70 \%$ were from Non-Asian regions. Previous studies revealed that the age category is very similar (Roggenbuck and Lucas, 1987; Lucas, 1990; Lindberg, 1991; Cheng, 1993; Hung, 1995; Wight, 1996; Ceballos,1996; Meric and Hunt,1998; Fennell and Nowaczek, 2003; Tao et al., 2004; Nepal, 2007). This finding shows that the participation of over 55 groups of Non-Asians and Asians is comparable.
Table 1: Age group

\begin{tabular}{lrr}
\hline Age group & Asian & Non-Asian \\
\cline { 2 - 3 } & $\%$ & $\%$ \\
\hline Below 16 & 3.4 & 0.7 \\
$16-25$ & 20.0 & 10.4 \\
$26-35$ & 30.0 & 33.4 \\
$36-45$ & 18.3 & 19.5 \\
$46-55$ & 15.0 & 20.5 \\
$56-65$ & 13.3 & 12.8 \\
Above 66 & - & 2.7 \\
\hline
\end{tabular}

\section{Education}

The educational standards of most of the ecolodge patrons show that they obtained degrees or above. Other studies (Meric and Hunt, 1998; Wight, 1996; Weaver, 2002; Fennell and Nowaczek, 2003; Nepal, 2007; Roggenbuck and Lucas, 1987; Lucas, 1990; Lindberg et al., 1998; Ceballos, 1996; Tao et al., 2004; Hung, 1995; Ou and Hsiao, 1998; Wang, 1995) showed similar results.

Table 2: Education levels

\begin{tabular}{lrr}
\hline Education level & Asian & Non-Asian \\
\cline { 2 - 3 } & $\%$ & $\%$ \\
\hline High-school or below & 28.3 & 20.9 \\
Bachelors degree & 23.3 & 32.0 \\
Graduate degree & 41.7 & 41.1 \\
PhD & 6.7 & 6.0 \\
\hline
\end{tabular}

\section{Party composition}

Predominant are tourists that arrive with a friend or spouse (38.3\% from Asia, 39\% from non-Asia, respectively) (Table 3). The least frequent category for both the Asian and non-Asian group was in organised groups.

Table 3: Party composition

\begin{tabular}{lrr}
\hline Party compositions & Asian & Non-Asian \\
\cline { 2 - 3 } & $\%$ & $\%$ \\
\hline Alone & 20.0 & 9.1 \\
Family & 16.7 & 20.6 \\
(with children) & & \\
With friend & 38.3 & 23.6 \\
Spouse & 16.7 & 39.0 \\
Organized group & 8.3 & 7.7 \\
\hline
\end{tabular}

\section{Travel characteristics}

The following section reports the travel characteristics and motivations of ecolodge patrons. There are three variables: (1) length of stay, (2) ecolodge motivation and (3) important ecolodge attributes. 
Both groups show similar length of stay patterns (Table 4). Non-Asian patrons were more likely to stay more than eleven days compared to Asian. It may be a characteristic of non-Asians to enjoy relaxing or enjoy the ecolodge environment and service, without rush.

Table 4: Length of stay at the ecolodge

\begin{tabular}{lrr}
\hline Number of nights & Asian & Non-Asian \\
\cline { 2 - 3 } & $\%$ & $\%$ \\
\hline $1-3$ & 56.7 & 61.3 \\
$4-7$ & 23.3 & 19.5 \\
$8-11$ & 13.3 & 8.1 \\
$12-15$ & 5.0 & 9.1 \\
$>15$ & 1.7 & 2.0 \\
\hline
\end{tabular}

\section{Travel motivation attributes}

The significance of 14 motivators were used and ranked. The following items are ranked according to the Likert scale from 1 (not at all important) to 7 (very important). The two groups ranked their top four attraction motives as follows: The Asian top four were: (1) Photography of landscape and wildlife; (2) Good opportunity for adventure; (3) National parks/wildness area; (4) The quality of accommodation. The non-Asian top four were: (1) Friendliness, (2) National parks/wildness area; (3) Different local food and (4) Learning local customs (Table 5). These were ranked in a range of 5.79-6.01.

Difference of local food is more important to nonAsian visitors. The Asian group favored photography of landscape and wildlife. For Asian visitors, being physically active is a stronger motivation than non-Asian visitors.

\section{Ecolodge choice attributes}

Based on ecolodge choice (Table 6), friendliness of staff (6.17) was rated highest for non-Asian patrons while, staff providing efficient services (5.88) was the top attribute for Asian patrons. Many attributes were more important to the non-Asian patrons than to the Asian patrons including: local food produced with local ingredients, ecolodge design appropriate to local setting, availability of library and material, availability of natural trail facilities, availability of trees and wildflowers around lodge, design sensitive to local environment with minimal negative impact, friendliness of staff, guided wildlife tours and quality of the environment or landscape.

Table 5: Ecolodge motivations attribute

\begin{tabular}{lrrrr}
\hline Ecolodge motives & \multicolumn{2}{c}{ Asian } & \multicolumn{2}{c}{ Non-Asian } \\
\cline { 2 - 5 } & Mean & St.Dev & Mean & St.Dev \\
\hline National parks/wildness area & 5.90 & 1.231 & 5.87 & 1.095 \\
Friendliness & 5.88 & 1.263 & 6.01 & 1.049 \\
Climate & 5.50 & 1.535 & 5.48 & 1.206 \\
Price level & 5.47 & 1.396 & 5.54 & 1.102 \\
Good opportunity for adventure & 5.93 & 1.087 & 5.69 & 1.144 \\
Personal safety & 5.77 & 1.140 & 5.79 & 1.210 \\
Difference of local food & 5.52 & 1.420 & 5.86 & 1.132 \\
Relaxing & 5.50 & 1.384 & 5.66 & 1.184 \\
Good opportunity to see historical sites & 5.52 & 1.546 & 5.39 & 1.220 \\
The quality of accommodation & 5.85 & 1.132 & 5.72 & 1.072 \\
Unique architecture & 5.65 & 1.436 & 5.44 & 1.226 \\
Photography of landscape and wildlife & 5.95 & 1.048 & 5.68 & 1.110 \\
Inexpensive good and services & 5.37 & 1.365 & 5.35 & 1.141 \\
Learning local customs & 5.60 & 1.317 & 5.79 & 1.070 \\
\hline
\end{tabular}

Note: Scale: $1=$ not at all important; 7 = very important 
Table 6: Ecolodge choice attributes

\begin{tabular}{|c|c|c|c|c|}
\hline \multirow[t]{2}{*}{ Ecolodge attributes } & \multicolumn{2}{|c|}{ Asian } & \multicolumn{2}{|c|}{ Non-Asian } \\
\hline & Mean & St.Dev & Mean & St.Dev \\
\hline Local food, produced with local ingredients & 5.67 & 1.410 & 6.06 & 1.145 \\
\hline A variety of lodging styles & 5.57 & 1.254 & 5.56 & 1.285 \\
\hline Ecolodge design appropriate to local setting & 5.52 & 1.432 & 6.09 & 1.068 \\
\hline Availability of actual habitat or species & 5.40 & 1.167 & 5.73 & 1.133 \\
\hline Availability of a library and material & 4.88 & 1.757 & 5.07 & 1.369 \\
\hline Availability of village cultural trip & 4.97 & 1.737 & 5.20 & 1.374 \\
\hline Availability of security personnel & 5.05 & 1.630 & 5.27 & 1.466 \\
\hline Availability of natural trail facilities & 5.35 & 1.516 & 5.85 & 1.142 \\
\hline Availability of trees and wildflowers around lodge & 5.62 & 1.403 & 6.08 & 1.129 \\
\hline Availability of observing wildlife & 5.83 & 1.107 & 5.97 & 1.090 \\
\hline Cleanliness & 5.63 & 1.461 & 5.76 & 1.153 \\
\hline Comfort of bed & 5.45 & 1.545 & 5.69 & 1.322 \\
\hline Convenient location, easy accessibility & 5.13 & 1.589 & 5.25 & 1.382 \\
\hline Decent sanitary condition & 5.75 & 1.385 & 5.72 & 1.240 \\
\hline Design sensitive to local environment with minimal negative impact & 5.65 & 1.260 & 6.12 & 1.031 \\
\hline Efficient reservation & 5.73 & 1.339 & 5.83 & 1.210 \\
\hline Friendliness of staff & 5.60 & 1.564 & 6.17 & 1.176 \\
\hline Guided wildlife tours & 5.32 & 1.535 & 5.72 & 1.211 \\
\hline High quality food & 5.78 & 1.342 & 5.92 & 1.234 \\
\hline Knowledgeable guides & 5.58 & 1.381 & 5.88 & 1.202 \\
\hline Provide private sleeping room, private washroom & 5.60 & 1.543 & 5.98 & 1.149 \\
\hline Quality of the environment or Landscape & 5.62 & 1.290 & 6.04 & 1.114 \\
\hline Reputation of lodge & 5.68 & 1.269 & 5.82 & 1.156 \\
\hline Staff provide efficient services & 5.88 & 1.250 & 6.02 & 1.092 \\
\hline Value for money & 5.62 & 1.462 & 5.79 & 1.149 \\
\hline
\end{tabular}

Note: Scale: $1=$ not at all important; 7 = very important.

\section{DISCUSSION}

In the Sri Lankan context this is the first study that refers to national and international ecotourists travelling in Sri Lanka. Previously many researches were done in North America and Australia.

Numerous studies have investigated the demographic characteristics of patrons. Many of these studies described an ecotourist as older than the average tourist, aged between 36 and 55 (Ballantine, 1991; Eagles and Cascagnette, 1995; Wight, 1996; Kawan et al., 2010). The present study indicates relatively younger patrons (30\%), between 26 to 35 years of age. Previous patrons profiling studies in Asian countries such as Thailand (Kerstetter et al., 2004) and Sri Lanka (Perera et al., 2012) found that the ecotourism market segment in these two countries is similarly characterised by young travellers.
In this study, the education level of patrons was high, most of them having obtained at least a first degree, similar to other empirical studies. The greater number of respondents were aged between 16 and 45 years. Most of the Asian ecotourists are likely to travel in small groups but non-Asians tend to travel with another adult (two people). Asians' travel motivation for Sri Lanka was photography of landscape and wildlife, nature-based tourism with the experience of adventure and for nonAsians motivation to travel to Sri Lanka was friendliness of the people of the country, followed by visiting natural areas, different local food and learning local customs. These results indicate that non-Asians conformed more to ecotourism, simila to Strasdas (2001).

The method of selection of a sample population for this research has many advantages: selecting ecolodge visitors as ecotourist is non bias than selecting visitors' 
natural areas, because as a mass, tourists visit the natural areas as part of their trip. Kawan et al. (2008; 2010) and Sumanapala et al. (2015) in their samples, similarly consider ecolodges patrons. This type of research is well suited to develop products and services to support decision making about ecotourism policy. Ecotourism services and product development that cater specifically for the Sri Lankan market will assist in keeping Sri Lankan ecotourism competitive in the world market. One conclusion may be to boost library facilities and ecolodge accessibility. For non-Asian ecotourists, improvements must reassure their personal security and safety measures for protection from external factors such as theft by locals and harm by wild animals.

\section{CONCLUSION}

The purpose of this study was to distinguish Asian and Non-Asian ecotourist market segments visiting ecolodges in Sri Lanka. This study contributes to the development of ecolodge industry in the country. The study uncovered the need to ameliorate weaknesses that deter ecolodge patrons and ways to maintain and increase high performance motives to increase visitors' satisfaction. Further, the study identifies attributes that show high satisfaction and less satisfaction among the ecolodge patrons.

Ecolodge owners and managers should consider ecolodge setting, activities and location as the main attributes that contribute to visitor satisfaction. Exposure to unique attributes will strengthen motivation and render price levels less of a consideration.

\section{ACKNOWLEDGMENT}

The authors of this paper would like to thank the National Research Council for providing financial assistance and the managements of the ecolodges that voluntarily participated in the survey.

\section{REFERENCES}

Akama, J. and Kieti, D. (2003) Measuring tourist satisfaction with Kenya's wildlife safari: a case study of Tsavo West National Park, Tourism Management, 24, pp: 73-81.

DOI: https://doi.org/10.1016/S0261-5177(02)00044-4

Atkinson, A. (1988) Answering the eternal question: what does the customer want?, The Cornell Hotel and Restaurant Administration Quarterly, 29 (2), pp: 12-14.

DOI: https://doi.org/10.1177/001088048802900209

Ballantine, J. L. and Eagles, P. F. J. (1994) Defining Canadian ecotourists, Journal of Sustainable Tourism, 2 (1), pp: 1-5.

DOI: https://doi.org/10.1080/09669589409510698
Callan, R. and Bowman, L. (2000) Selecting a hotel and determining salient quality attributes: a preliminary study of mature British travelers, International Journal of Tourism Research, 2(2), pp: 97-118.

D O I : h t tps:// d o i o r g / 10.1002 / ( S I C I ) 1522 1970(200003/04)2:2<97::AID-JTR190>3.0.CO;2-1

Callan, R. and Kyndt, G. (2001) Business travellers' perception of service quality: a prefatory study of two European city centre hotels, International Journal of Tourism Research, 3(4), pp: 313323.

DOI: https://doi.org/10.1002/jtr.333

Ceballos-Lascurain, H. (1996) Tourism, ecotourism, and protected areas: The state of nature-based tourism around the world and guidelines for its development, Gland, Switzerland: IUCN.

DOI: https://doi.org/10.2305/IUCN.CH.1996.7.en

Chan, J. and Baum, T. (2007) Motivation factors of ecotourists in ecolodge accommodation: the push and pull factors, Asia Pacific Journal of Tourism Research, pp: 101-109.

Cheng, L. (1993) Visitor's socio-demographic characteristics, recreation activity patterns and attitudes toward Yushan National Park policies in Taiwan. The Republic of China - a survey, School of Natural Resources, Ohio: Ohio State University.

Chu, R. and Choi, T. (2000) An importance-performance analysis of hotel selection factors in the Hong Kong hotel industry: a comparison of business and leisure travelers, Tourism Management, 21 (4). pp: 363-377.

DOI: https://doi.org/10.1016/S0261-5177(99)00070-9

Dolnicar, S. and Grun, B. (2008) Challenging "factor cluster segmentation, Journal of Travel Research, 47(1), pp: 63-71.

DOI: https://doi.org/10.1177/0047287508318910

Eagles, P. F. and Cascagnette, J. W. (1995) Canadian ecotourists: who are they?, Tourism Recreation Research, 20(1), pp: 22-28. DOI: https://doi.org/10.1080/02508281.1995.11014729

Eagles, P. F. (1992) The travel motivations of Canadian ecotourists, Journal of Travel Research, 3, pp: 3-5.

DOI: https://doi.org/10.1177/004728759203100201

Erdem, M. (2013) Exploring the behavioral aspects of adopting technology: meeting planners' use of social network media and the impact of perceived critical mass, Journal of Hospitality and Tourism Technology, 4, pp: 6-22.

DOI: https://doi.org/10.1108/17579881311302329

Fennell, D. and Nowaczek, A. (2003) An examination of values and environmental attitudes among ecotourists: a descriptive study involving three samples, Tourism Recreation Research, 28 (1), pp: 11-21.

DOI: https://doi.org/10.1080/02508281.2003.11081382 
Fennell, D. A. (2001) A content analysis of ecotourism definitions, Current Issues in Tourism, 4, pp: 403-421.

DOI: https://doi.org/10.1080/13683500108667896

Hawkins, D., EplerWood, M. and Bittman, S. (1995) The Ecolodge Sourcebook, North Bennington: The Ecotourism Society.

Hung, S. (1995) The study of the tourists' attitude towards ecotourism - application on the Yangminshan National Park (in Chinese), Taipei: National Taiwan University.

Kerstetter, D. L., Hou, J. S. and Lin, C. H. (2004) Profiling Taiwanese ecotourists using a behavioral approach, Tourism Management, 25(4), pp: 491-498.

DOI: https://doi.org/10.1016/S0261-5177(03)00119-5

Kim, L. C. and Baum, T. (2007) Motivation factors of ecotourists in ecolodge accommodation: the push and pull factors, Asia Pacific Journal of Tourism Research, 12(4), pp: 349-364.

DOI: https://doi.org/10.1080/10941660701761027

Kozak, M. (2001) Comparative assessment of tourist satisfaction with destinations across two nationalities, Tourism Management, 22, pp: 391-401.

DOI: https://doi.org/10.1016/S0261-5177(00)00064-9

Kwan, P., Eagles, P. and Gebhardt, A. (2008) A comparison of ecolodge patrons' characteristics and motivations based on price levels: a case study of Belize, Journal of Sustainable Tourism, 16(6), pp: 698-718.

DOI: https://doi.org/10.1080/09669580802397129

Kwan, P., Eagles, P. and Gebhardt, A. (2010) Ecolodge patrons' characteristics and motivations: a study of Belize, Journal of Ecotourism, 9(1), pp: 1-20.

DOI: https://doi.org/10.1080/14724040802140576

Lai, P. and Shafer, S. (2005) Marketing ecotourism through the internet: an evaluation of selected ecolodges in Latin America and the Caribbean, Journal of Ecotourism, 4(3), pp: 143-160.

DOI: https://doi.org/10.1080/JET.v4.i3.pg143

LeBlanc, G. and Nguyen, N. (1996) An examination of the factors that signal hotel image to travelers, Journal of Vacation Marketing, 3(1), pp: 32-42.

DOI: https://doi.org/10.1177/135676679600300103

Lindberg, K., Furze, B., Staff, M. and Black, R. (1998) Ecotourism in the Asia-Pacific region: issues and outlook, Rome: United Nations Food and Agriculture Organization.

Lindberg, K. (1991) Policies for Maximizing nature tourism's ecological and economic benefits, Washington: World Resources Institute.

Lucas, R. (1990) Wilderness use and users: trends and projections in wilderness recreation management: an overview, Colorado: North American Press.
Mehta, B., Baez, A. and O'Loughlin, P. (2002) International Ecolodge Guidelines, North Bennington: The International Ecotourism Society.

Meric, H. and Hunt, J. (1998) Ecotourists' motivational and demographic characteristics: a case of North Carolina travelers, Journal of Travel research, 36(4), pp: 57-61.

DOI: https://doi.org/10.1177/004728759803600407

Nepal, S. (2007) Tourism and rural settlements Nepal's Annapurna region, Annals of Tourism Research, 34(4), pp: 855-875.

DOI: https://doi.org/10.1016/j.annals.2007.03.012

Oppermann, M. and Chon, K. (1997) Tourism in developing countries, London: International Thomson Press.

Ou, S. and Hsiao, Y. (1998) A study on ecotourists' characteristics (in Chinese), Journal of Outdoor Recreation Study, 11 (3), pp: 35-58.

Perera, P., Vlosky, R. P. and Wahala, S. B. (2012) Motivational and behavioral profiling of visitors to forest-based recreational destinations in Sri Lanka, Asia Pacific Journal of Tourism Research, 17(4), pp: 451-467.

DOI: https://doi.org/10.1080/10941665.2011.627353

Raju, G. (2009) Tourism marketing and management, Delhi: Manglam Publications.

Roggenbuck, J. and Lucas, R. C. (1987) Wilderness use and user characteristics: a state-of knowledge review, National Wilderness Research Conference: Issues, State-of-Knowledge, Future Directions, Ogdn: US Department of Agriculture.

Russell, D., Bottrill, C. and Meredith, G. (1995) Introduction: International Ecolodge Survey, North Bennington: The Ecotourism Society.

Sanders, E. and Halpenny, E. (2001) The business of ecolodges: a survey of ecolodge economics and finance, Burlington, VT: The International Ecotourism Society.

Strasdas, W. (2001) Ecotourism in practice the implementation of the economic and conservation-related goals of an ambitious tourism concept in developing countries, Ammerland, Germany: Institute for Tourism and Development.

Sumanapala, H., Perera, P., Kotagama, S. and Silva, D. (2015) Eco-lodge Patrons' Characteristics: the Sri Lankan perspective, International Journal of Research in Social Sciences, 5(2), pp: 509-525.

Tao, C.-H., Eagles, P. \& Smith, S. (2004) Implications of alternative definitions of ecotourists, Tourism Analysis, 9, pp: $1-13$.

DOI: https://doi.org/10.3727/1083542041437585

Wang, P. (1995) The relationships between visitors' environmental attitudes and ecotourism management - a case 
study of Guan-duh Wetland (in Chinese), Taiwan: Tunghai University.

Weaver, D. (2002) Asian ecotourism: patterns and themes, tourism geographies, An International Journal of Tourism Space, Place and Environment, 4(2), pp: 153-172.

Weaver, D. and Lawton, L. (2002) Overnight ecotourists market segmentation in the Gold Coast hinterland of Australia, Journal of Travel Research, 40(3), pp: 270-280.

DOI: https://doi.org/10.1177/004728750204000305

Weaver, D. B. (2001) Ecotourism as mass tourism: contradiction or reality?, Cornell Hospitality Quarterly, 42, pp: 104-112.

DOI: https://doi.org/10.1016/S0010-8804(01)80022-7
Weaver, D. B. (2002) Hard-core Ecotourists in Lamington National Park, Australia, Journal of Ecotourism, 1(1), pp: 1935 .

DOI: https://doi.org/10.1080/14724040208668110

Wight, P. (1996) North American ecotourists: motivations, preferences and destinations, Journal of Travel Research, 35(6), pp: 3-8.

Wilensky, L. and Buttle, F. (1998) A multivariate analysis of hotel benefit bundles and choice trade-offs, International Journal of Hospitality Management, 7(1), pp: 29-41.

DOI: https://doi.org/10.1016/0278-4319(88)90008-4

World Tourism Organization (2002) The Canadian Ecotourism Market [Special Report No. 15], Spain: World Tourism Organization. 